\title{
Stage IV Major Salivary Gland Carcinoma without Metastasis
}

National Cancer Institute

\section{Source}

National Cancer Institute. Stage IV Major Salivary Gland Carcinoma without Metastasis. NCI Thesaurus. Code C5900.

Stage IV carcinoma of the major salivary glands without regional lymph nodes or distant metastases. 